\title{
Mistisisme Musik Iringan Kesenian Reog Ponorogo
}

\author{
Dhani Kristiandri \\ Program Studi Seni Musik Jurusan Sendratasik FBS Unesa \\ Email: dhanikristiandri@unesa.ac.id
}

\begin{abstract}
Reog Ponorogo is a traditional art from Ponorogo which has special characteristics. Distinctive accompaniment, unique offerings and mystical nuances often accompany this form of art. This was especially evident in the accompaniment presented. The focus of this article discussion on the presence of accompaniment in the Reog Ponorogo art which has a mystical nuance. With the support of a number of special instruments, such as trumpets, gongs, drums, etc., the rhythm and nuances presented are very mystical. Previous research that discusses the art of Reog Ponorogo, namely Setyo Yuwana (1995) with the title "Reog Ponorogo: Dramatic Structure, Social Function, and Its Symbolic Meaning". Yuwana took the research object of Reog Ponorogo Circle of Friends Anom and Jayeng Katong in Ponorogo Regency. The contribution of Yuwana's research in this article is that it can be used by researchers as an insight into the Reog Ponorogo show in the Ponorogo district that has not been packaged and still has a complete show structure, as well as with the function and meaning of the show intact. Thus, researchers are more focused on examining the Reog Ponorogo show that has been packaged in a packaging show at the Surabaya Youth Hall. Data collection techniques used three ways namely, observation, interview, and documentation. Traditional existence wherever it has been excluded, is considered to have no place in today's society, then efforts to preserve and develop arts need to be increased. It is hoped that through preservation efforts through various packages can help the next generation to appreciate and process creatively.
\end{abstract}

Keywords: Mysticism, Accompanied Music, Reog Ponorogo.

\begin{abstract}
Abstrak: Reog Ponorogo merupakan kesenian tradisional dari Ponorogo yang memiliki karakteristik khusus. Iringan yang khas, sajian yang unik dan nuansa yang mistis seringkali menyertai bentuk kesenian ini. Hal itu terutama tampak pada iringan yang disajikan. Fokus pembahasan artikel ini pada hadirnya iringan dalam kesenian Reog Ponorogo yang memiliki nuansa mistis. Dengan didukung beberapa instrumen khusus, seperti terompet, gong, kendang, dan lain-lain, irama dan nuansa yang dihadirkan sangat terasa nuansa mistisnya. Penelitian sebelumnya yang membahas tentang kesenian Reog Ponorogo, yaitu Setyo Yuwana (1995) dengan judul "Reog Ponorogo: Struktur Dramatik, Fungsi Sosial, dan Makna Simboliknya". Yuwana mengambil objek penelitian Reog Ponorogo Paguyuban Pujangga Anom dan Jayeng Katong di Kabupaten Ponorogo. Kontribusi penelitian Yuwana pada artikel ini adalah dapat digunakan peneliti sebagai wawasan pada pertunjukan Reog Ponorogo yang berada di kabupaten Ponorogo yang belum dikemas dan masih dengan struktur pertunjukan yang lengkap, serta dengan fungsi dan makna pertunjukan yang utuh. Dengan demikian, peneliti lebih terarah mengkaji pertunjukan Reog Ponorogo yang telah dikemas dalam pertunjukan kemasan di Balai Pemuda Surabaya. Teknik pengumpulan data menggunakan tiga cara yaitu, observasi, wawancara, dan dokumentasi. Eksistensi tradisional di mana pun memang telah tersisihkan, dianggap tidak memiliki tempat dalam masyarakat kini, maka upaya pelestarian dan pengembangan kesenian perlu ditingkatkan. Diharapkan melalui upaya pelestarian melalui berbagai kemasan dapat membantu generasi penerus untuk berapresiasi dan berproses kreatif.
\end{abstract}

Kata Kunci: Mistisisme, Musik Iringan, Reog Ponorogo.

\section{PENDAHULUAN}

Surabaya merupakan ibukota Jawa Timur yang memiliki karakteristik budaya masyarakat sebagai budaya metropolis dengan berbagai bentuk seni pertunjukan yang dapat bertahan hidup dalam lingkungan masyarakatnya. Sebagai upaya untuk menghidupkan dan memperkenalkan keberadaan seni pertunjukan tradisional di masyarakat, Dinas Pendidikan Propinsi Jawa Timur dan Dinas Pariwisata Kota Surabaya mengkemas seni pertunjukan tradisional dalam kemasan yang ditampilkan secara rutin. Pengkemasan pertunjukan ditampilkan secara periodik di berbagai tempat, di antaranya pentas rutin di Taman Budaya Surabaya yang mengagendakan pentas tiap bulan dengan berbagai seni pertunjukan daerah yang ada di Jawa Timur. Pentas rutin dilakukan setiap dua minggu sekali, dalam bentuk pertunjukan seni tradisional di Taman Hiburan Rakyat Surabaya dengan materi pertunjukan kesenian Ludruk, Wayang Orang, dan Ketoprak, serta di Balai Pemuda pada setiap hari minggu dengan seni pertunjukan Jaranan dan Reog Ponorogo. 
Pertunjukan di Balai Pemuda Surabaya yang dilakukan rutin pada setiap hari Minggu pagi, sekitar pukul 08.00 hingga pukul 10.00 WIB merupakan pertunjukan yang telah dapat bertahan dalam kurun waktu lebih dari 8 (delapan) tahun. Pertunjukan dilakukan bergantian pada setiap minggunya, yaitu pertunjukan Jaranan dan Reog Ponorogo. Selama pertunjukan berlangsung, penonton relatif banyak, dengan kategori penonton yang heterogen, mulai dari kalangan anak-anak hingga orang dewasa.

Reog Ponorogo sebagai materi pertunjukan di Balai Pemuda dari hasil pengamatan peneliti memberikan kesan menarik dalam pertunjukannya. Peran yang dibawakan oleh pemain dengan berbagai karakter membuat pertunjukan lebih bervariasi dan tidak membosankan. Di samping itu, terdapat adegan lucu sebagai intermezo atraksi pertunjukan sehingga penonton yang melihat menjadi tertawa dan terhibur melihat pertunjukan. Pemain juga melakukan komunikasi dengan penonton yang dilakukan di sela pertunjukan, yaitu dengan menyapa penonton dan mengajak dialog, kemudian dilanjutkan dengan pertunjukan kembali.

Fokus pembahasan artikel ini pada hadirnya iringan dalam kesenian Reog Ponorogo yang memiliki nuansa mistis. Dengan didukung beberapa instrumen khusus, seperti terompet, gong, kendang, dan lain-lain, irama dan nuansa yang dihadirkan sangat terasa nuansa mistisnya.

\section{KAJIAN PUSTAKA}

Penelitian sebelumnya yang membahas tentang kesenian Reog Ponorogo, yaitu Setyo Yuwana (1995) dengan judul "Reog Ponorogo: Struktur Dramatik, Fungsi Sosial, dan Makna Simboliknya" merupakan penelitian dengan yang relevan dengan penelitian ini. Yuwana mengambil objek penelitian Reog Ponorogo Paguyuban Pujangga Anom dan Jayeng Katong yang ada di desa Kauman, Kecamatan Kauman, Kabupaten Ponorogo. Kajian penelitian ini cukup kompleks dengan mengkaji struktur lakon, fungsi sosial dan model pengetahuan masyarakat yang terekspresi dalam pertunjukan Reog Ponorogo. Berdasarkan hasil penelitian tentang struktur pertunjukan yang dikaji melalui lakon, ditemukan struktur adegan pertunjukan yang terdiri dari adegan Tari Warok, adegan Tari Jathilan, adegan Tari Bujangganong, adegan tari Klono Sewandana, adegan tari Barong Lepas, adegan Perang Jathilan dengan Dhadhak Merak, adegan Perang Klana Sewandana dengan Dhadhak Merak, adegan tari Merak Tarung dan adegan iring-iringan. Dijelaskan pula dalam struktur pertunjukan mengenai karakter tokoh dan elemen pertunjukan. Fungsi sosial Reog Ponorogo di desa Kauman sebagai media pendidikan; alat penebal rasa solidaritas; alat yang memungkinkan orang bertindak dengan penuh kekuasaan; alat mengeluarkan protes sosial terhadap ketidakadilan; dan sebagainya, sedangkan makna simbolik pertunjukan ditemukan dalam sikap dan gerak tari.

Penelitian Yuwana tersebut relevan dengan artikel ini karena objek kajian yang digunakan adalah seni pertunjukan Reog Ponorogo. Namun demikian, terdapat perbedaan objek yaitu Reog Ponorogo yang dikaji oleh Yuwana adalah pertunjukan tradisional yang berada dalam lingkup masyarakat pendukungnya yaitu di Desa Kauman, Kecamatan Kauman Kabupaten Ponorogo; sedangkan objek kajian dalam penelitian ini adalah seni pertunjukan Reog Ponorogo yang berkembang di kota Surabaya, yang eksis dengan pertunjukan rutinnya di Balai Pemuda Surabaya.

Di samping itu, pengkajian Yuwana dilakukan dengan mengkaji seluruh aspek pertunjukan yang dilakukan pada 2 (dua) kelompok paguyuban, yaitu Pujangga Anom dan Jayeng Katong yang tentu saja hasil kajian menjadi kompleks; sedangkan artikel ini memfokuskan pertunjukan Reog Ponorogo yang telah dikemas dalam durasi waktu 1 (satu) hingga 2 (dua) jam saja dengan mengkaji struktur dan fungsi sosial pertunjukan.

Kontribusi penelitian Yuwana pada artikel ini adalah dapat digunakan peneliti sebagai wawasan pada pertunjukan Reog Ponorogo yang berada di kabupaten Ponorogo yang belum dikemas dan masih pertunjukan dengan struktur pertunjukan yang lengkap, serta dengan fungsi dan makna pertunjukan yang utuh. Dengan mengetahui bagaimana pertunjukan yang lengkap dan utuh, maka peneliti lebih terarah mengkaji pertunjukan Reog Ponorogo yang telah dikemas dalam pertunjukan kemasan di Balai Pemuda Surabaya.

\section{METODE PENELITIAN}

Lokasi penelitian di Balai Pemuda Surabaya sebagai tempat pertunjukan Reog Ponorogo. Di Balai Pemuda Surabaya, Reog Ponorogo dipentaskan setiap 2 (dua) minggu sekali (menyesuai jadwal periodik Dinas Pariwisata). Waktu pementasan dilakukan sekitar 1 (satu) 
hingga 2 (dua) jam pertunjukan. Objek penelitian adalah seni pertunjukan Reog Ponorogo yang tampil di Balai Pemuda Surabaya, yaitu kelompok Persatuan Unit-Unit Reog Ponorogo Surabaya yang disingkat 'PUR-BAYA', pimpinan Bapak H. Nirwono, SH.

Teknik pengumpulan data menggunakan 3 (tiga) cara yaitu, melalui observasi, wawancara, dan dokumentasi. Pengumpulan data dalam penelitian ini dimaksudkan untuk memperoleh bahan, keterangan, atau informasi yang tepat dan dipercaya. Pengumpulan teknik dan alat yang tepat memungkinkan data yang obyektif (Arikunto, 1998:142). Adapun teknik pengumpulan data yang digunakan, sebagai berikut:

\section{Observasi}

Teknik pengumpulan data dengan observasi dilakukan peneliti untuk mendapatkan informasi tentang struktur pertunjukan Reog Ponorogo yang ditampilkan di Balai Pemuda Surabaya. Dengan melihat secara langsung pertunjukan mulai persiapan, pelaksanaan, dan akhir pertunjukan maka diketahui dengan lengkap struktur pertunjukan Reog Ponorogo. Arikunto (1998:146) menjelaskan bahwa pengumpulan data dengan observasi merupakan pengamatan yang meliputi perbuatan pemantauan terhadap suatu obyek yang menggunakan seluruh alat indra atau pengamatan langsung.

Kegiatan observasi dalam penelitian ini dilakukan di lokasi pertunjukan Reog Ponorogo dengan mengamati kondisi fisik lokasi dan kondisi pertunjukan untuk menjelaskan struktur pertunjukan Reog Ponorogo. Kegiatan observasi didukung dengan teknik dokumentasi melalui perekaman video pertunjukan dan foto pertunjukan agar data struktur pertunjukan akan lebih akurat.

\section{Wawancara}

Wawancara adalah tehnik pengumpulan data untuk menemukan permasalahan yang diteliti, dan juga apabila peneliti ingin mengetahui hal dari responden yang lebih mendalam (Sugiono, 2007: 137). Wawancara dalam penelitian ini digunakan untuk mengkaji fungsi seni pertunjukan Reog Ponorogo bagi pelaku seni dan masyarakat. Moleong (2002:135) menjelaskan bahwa wawancara adalah percakapan yang dilakukan oleh dua pihak yaitu pewawancara (interviewer) yang mengajukan pertanyaan dan pihak yang diwawancarai (interview) yang memberikan jawaban atas pertanyaan tersebut.
Wawancara dalam penelitian harus dilakukan dengan efektif, yang artinya dalam waktu yang sesingkat-singkatnya untuk mendapatkan data sebanyak-banyaknya. Selanjutnya, Arikunto (1998:129) menekankan wawancara dilakukan dengan bahasa yang jelas, bahasan terarah, dengan suasana rileks agar data yang diperoleh obyektif dan dapat dipercaya.

Wawancara yang digunakan dalam penelitian ini adalah wawancara bebas terpimpin dengan peneliti membawa garis besar pedoman wawancara yang selanjutnya dikembangkan di lapangan dan tetap pada tujuan wawancara yaitu mendapatkan data tentang struktur dan fungsi seni pertunjukan Reog Ponorogo. Wawancara dengan materi struktur pertunjukan dilakukan pada pemimpin pertunjukan dan pelaku pertunjukan; sedangkan wawancara dengan materi fungsi seni pertunjukan dilakukan pada pelaku seni dan masyarakat penonton pertunjukan.

\section{Dokumentasi}

Dokumen adalah semua jenis rekaman/catatan sekunder, lainnya seperti suratsurat, memo/nota, pidato, buku harian, foto-foto, kliping berita koran, hasil-hasil penelitian, agenda kegiatan (Faisal, 1990:81). Dokumentasi dalam penelitian ini dikelompokkan dalam dua bagian, yaitu dokumen video pertunjukan dan dokumen foto pertunjukan dan suasana lokasi pertunjukan. Dokumen video pertunjukan digunakan untuk mengkaji struktur pertunjukan Reog Ponorogo. Foto pertunjukan juga digunakan untuk menjelaskan struktur pertunjukan; sedangkan foto suasana lokasi pertunjukan saat pertunjukan berlangsung digunakan untuk menjelaskan fungsi sosial pertunjukan Reog Ponorogo.

Miles and Huberman (dalam Sugiyono, 2011 :337) menjelaskan bahwa analisis data dalam penelitian ini merujuk konsep yang mengelompokkan aktivitas dalam tiga bagian, yaitu reduksi data, penyajian data, penarikan kesimpulan dan verifikasi data. Dalam penelitian konsep tersebut selanjutnya dijabarkan sebagai berikut.

\section{Reduksi Data}

Reduksi data dalam penelitian ini dilakukan dengan memilahkan data berdasarkan kelompok kajian dan mendeskripsikan hasil tiap kelompok kajian tersebut. Hal ini dilakukan untuk memudahkan pengkajian penelitian selanjutnya. Selanjutnya dalam reduksi data juga akan dikelompokkan berdasarkan permasalahan 
dalam penelitian yaitu tentang struktur pertunjukan dan fungsi sosial pertunjukan Reog Ponorogo yang dipentaskan di Balai Pemuda Surabaya.

\section{Penyajian Data}

Penyajian data dilakukan melalui deskriptif kualitatif dengan bentuk uraian hasil reduksi data. Penyajian data dilakukan dengan pengelompokkan data untuk memudahkan pemahaman tentang data struktur dan data fungsi pertunjukan.

\section{Penarikan Kesimpulan dan Verifikasi}

Kesimpulan dan verifikasi dalam penelitian ini diperoleh dari hasil penyajian data yang telah dianalisis. Penarikan kesimpulan dilakukan dengan mendeskripsikan hasil penelitian yang dikelompokkan sesuai permasalahan dalam penelitian. Kesimpulan dan verifikasi ini selanjutnya menjadi hasil temuan dalam penelitian ini.

\section{Validitas Data.}

Validitas data dalam penelitian ini dilakukan dengan mengcroscek data hasil observasi dengan data dari wawancara, dan data dokumentasi dari pertunjukan.

\section{Skema Desain Penelitian}

Adapun skema desain penelitian ini dapat digambarkan sebagai berikut:

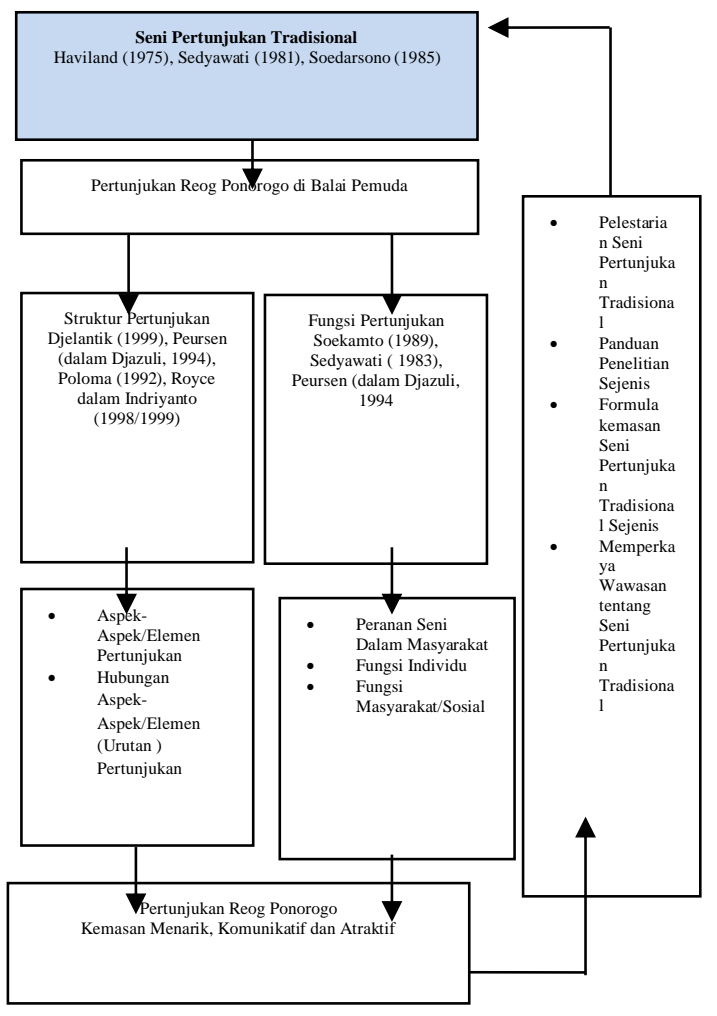

Skema 1. Desain Penelitian

\section{HASIL PENELITIAN DAN PEMBAHASAN Seni Pertunjukan}

Haviland (1975:11) yang mengungkapkan seni pertunjukan sebagai bagian dari kesenian yang diwujudkan dari bentuk-bentuk yang ditampilkan secara ekspresif dari seseorang dapat berupa seni tari, seni karawitan, seni musik, seni deklamasi dan seni drama.

Sedyawati (1981:60) menjelaskan bahwa hakikat dari seni pertunjukan adalah gerak yaitu perubahan dari suatu keadaan yang substansinya terletak pada imajinasi serta prosesnya sekaligus. Dijelaskan pula bahwa daya rangkum adalah sarananya, suatu cekaman rasa adalah tujuan seninya, ketrampilan teknis adalah bahannya, sedangkan lokasi adalah waktu dimana suatu ungkapan seni itu berlangsung. Dijelaskan pula oleh Sedyawati (1981:60-61) bahwa suatu bentuk seni pertunjukan tradisional dapat mengikuti pola berulang dalam segi ketrampilan teknis tetapi pada unsur lainnya selalu mengandung unsur perubahan. Pola berulang dalam seni pertunjukan tradisi diartikan sebagai bentuk kelanjutan masa lalu sebagai warisan yang terjadi secara turun temurun diwariskan oleh nenek moyang. Bentuk seni pertunjukan telah menyatu dengan masyarakat yang juga berkaitan dengan adat istiadat dan sifat kedaerahan dari asal usul seni pertunjukan. Sebagai bentuk produk rakyat yang hidup, tumbuh dan berkembang dalam lingkungan sosial budaya masyarakatnya, seni pertunjukan memiliki gaya dan ciri-ciri yang spontan.

Keberadaan seni pertunjukan tradisional pada jaman modern dihadapkan pula dengan seni pertunjukan moden dan seni pertunjukan massa yang oleh Soedarsono (1985:268) diasumsikan bahwa seni pertunjukan tradisional saat ini ditopang oleh kepentingan, di antaranya kepentingan ritual dan kepentingan proyek yang merupakan upaya pelestarian dan peningkatan mutu penyajian seni pertunjukan.

Konsep tersebut di atas digunakan untuk menjelaskan eksistensi seni pertunjukan Reog Ponorogo yang dapat tampil rutin di Balai Pemuda dalam bentuk kemasan pertunjukan.

Berikut paparan mengenai alat music yang digunakan dalam pertunjukan Reog Ponorogo: 


\section{Kendhang}

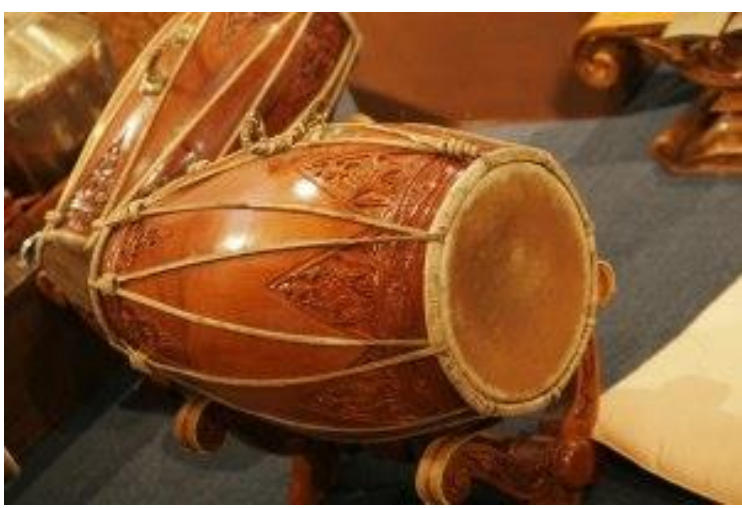

Gambar 1. Kendhang

Terbuat dari kulit hewan (Sapi atau kambing) berfungsi utama untuk mengatur irama. Kendhang ini dibunyikan dengan tangan, tanpa alat bantu. Jenis kendang yang kecil disebut ketipung, yang menengah disebut kendhang ciblon/kebar. Pasangan ketipung ada satu lagi bernama kendang gedhe biasa disebut kendang kalih. Kendang kalih dimainkan pada lagu atau gendhing yang berkarakter halus seperti ketawang, gendhing kethuk kalih, dan ladrang irama dadi. Bisa juga dimainkan cepat pada pembukaan lagu jenis lancaran, ladrang irama tanggung. Untuk bermain kendhang, dibutuhkan orang yang sangat mendalami budaya Jawa, dan dimainkan dengan perasaan naluri si pemain, tentu saja dengan aturan-aturan yang ada.

\section{Demung, Saron, Peking}

Alat ini berbentuk bilahan dengan enam atau tujuh bilah (satu oktaf) ditumpangkan pada bingkai kayu yang juga berfungsi sebagai resonator. Instrumen mi ditabuh dengan tabuh dibuat dari kayu. Menurut ukuran dan fungsinya, terdapat tiga jenis saron: (1) Demung (Paling besar), (2) Saron (Sedang) dan, (3) Peking (Paling kecil).

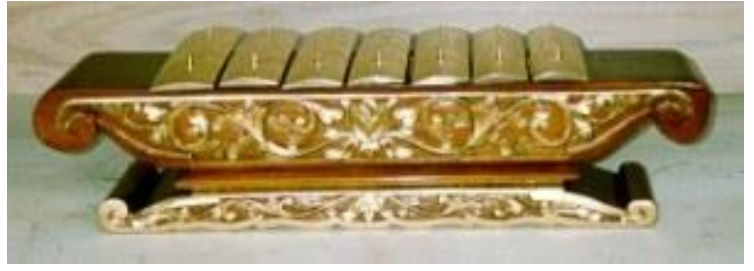

Gambar 2. Demung

Alat ini berukuran besar dan beroktaf tengah. Demung memainkan balungan gendhing dalam wilayahnya yang terbatas. Umumnya, satu perangkat gamelan mempunyai satu atau dua demung, tetapi ada gamelan di kraton yang mempunyai lebih dari dua demung.

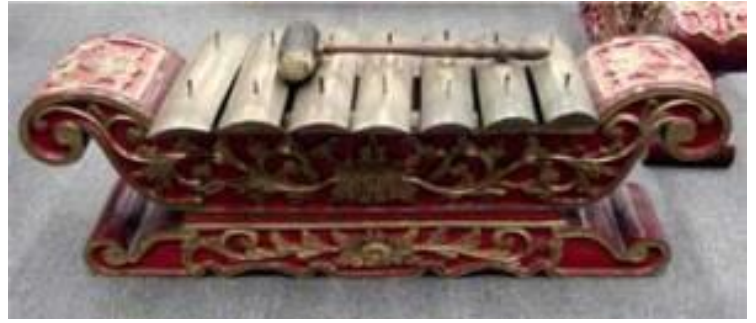

Gambar 3. Saron

Alat ini berukuran sedang dan beroktaf tinggi. Sama seperti demung, saron barung memainkan balungan dalam wilayahnya yang terbatas. Pada teknik tabuhan imbal-imbalan, dua saron memainkan lagu jalin-menjalin yang bertempo cepat. Seperangkat gamelan mempunyai dua saron, tetapi ada gamelan yang mempunyai lebih dan dua saron.

Peking. Berbentuk saron yang paling kecil dan beroktaf paling tinggi. Saron panerus atau peking ini memainkan tabuhan rangkap dua atau rangkap empat lagu balungan.

\section{Gong dan Kempul}

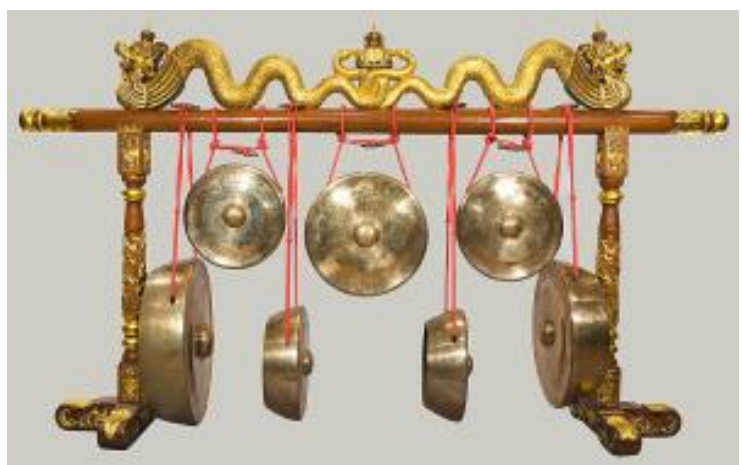

Gambar 4. Gong dan Kempul

Gong menandai permulaan dan akhiran gendhing, serta memberi rasa keseimbangan setelah berlalunya kalimat lagu gendhing yang panjang. Gong sangat penting untuk menandai berakhirnya satuan kelompok dasar lagu, sehingga kelompok itu sendiri (yaitu kalimat lagu di antara dua tabuhan gong) dinamakan 'gongan'. Ada dua macam gong, yakni (1) Gong Ageng (besar) dan (2) Gong Suwukan atau Gong Siyem yang berukuran sedang.

\section{Bonang}

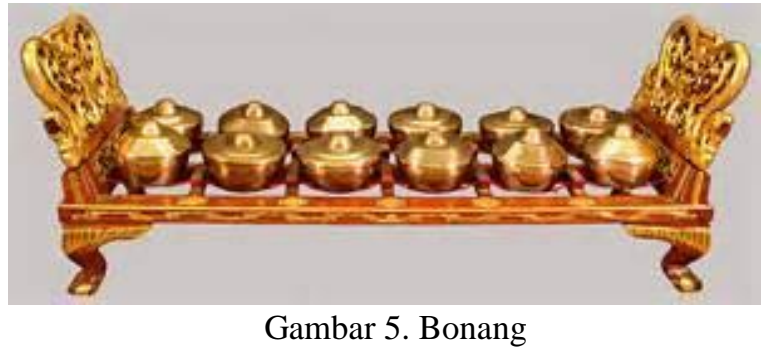


Bonang dibagi menjadi dua jenis, yaitu bonang barung dan bonang panerus. Perbedaannya pada besar dan kecilnya saja, dan juga pada cara memainkan iramanya. Bonang barung berukuran besar, beroktaf tengah sampai tinggi, adalah salah satu dari instrumeninstrumen pemuka dalam ansambel. Khususnya dalam teknik tabuhan pipilan, pola-pola nada yang selalu mengantisipasi nada-nada yang akan datang dapat menuntun lagu instrumeninstrumen lainnya. Pada jenis gendhing bonang, bonang barung memainkan pembuka gendhing dan menuntun alur lagu gendhing. Pada teknik tabuhan imbal-imbalan, bonang barung tidak berfungsi sebagai lagu penuntun; ia membentuk pola-pola lagu jalin-menjalin dengan bonang penerus, dan pada aksen penting, bonang dapat membuat sekaran (lagu-lagu hiasan), biasanya di akhiran kalimat lagu.

Bonang panerus adalah bonang yang kecil, beroktaf tinggi. Pada teknik tabuhan pipilan, irama bonang panerus memiliki kecepatan dalam bermain dua kali lipat dari pada bonang barung. Walaupun mengantisipasi nada-nada balungan, bonang penerus tidak berfungsi sebagai lagu tuntunan, karena kecepatan dan ketinggian wilayah nadanya. Dalam teknik tabuhan imbalimbalan, bekerja sama dengan bonang barung, bonang panerus memainkan pola-pola lagu jalin menjalin.

\section{Slenthem}

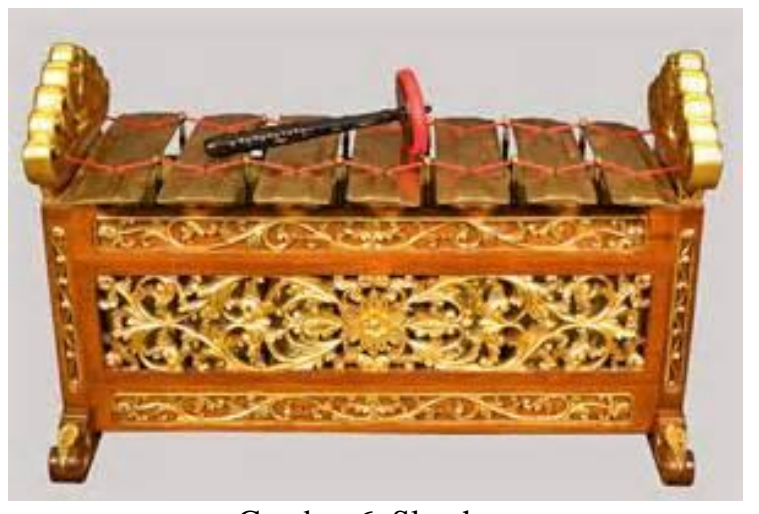

Gambar 6. Slenthem

Menurut konstruksinya, slenthem termasuk keluarga gender; terkadang ia dinamakan gender panembung, tetapi slenthem mempunyai bilah sebanyak bilah saron; Slenthem beroktaf paling rendah dalam kelompok instrumen saron. Seperti demung dan saron barung, slenthem memainkan lagu balungan dalam wilayahnya yang terbatas.

\section{Kethuk dan Kenong}

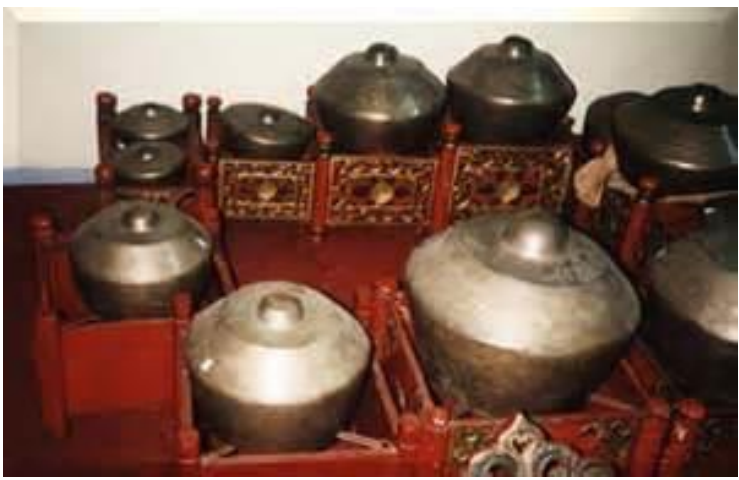

Gambar 7. Kethuk dan Kenong

Kenong merupakan satu set instrumen jenis mirip gong berposisi horisontal, ditumpangkan pada tali yang ditegangkan pada bingkai kayu. Dalam memberi batasan struktur suatu gendhing, kenong adalah instrumen kedua yang paling penting setelah gong. Kenong membagi gongan menjadi dua atau empat kalimat kalimat kenong. Di samping berfungsi menggaris-bawahi struktur gendhing, nada kenong juga berhubungan dengan lagu gendhing; ia bisa memainkan nada yang sama dengan nada balungan; ia boleh juga mendahului nada balungan berikutnya untuk menuntun alun lagu gendhing; atau ia dapat memainkan nada berjarak satu kempyung dengan nada balungan, untuk mendukung rasa pathet. Pada kenongan bergaya cepat, dalam 'ayak-ayakan', 'srepegan', dan 'sampak', tabuhan kenong menuntun alur lagu gendhing-gendhing tersebut. Kethuk sama dengan kenong, fungsinya juga sama dengan kenong. Kethuk dan kenong selalu bermain jalin-menjalin, perbedaannya pada irama bermainnya saja.

\section{Gender}

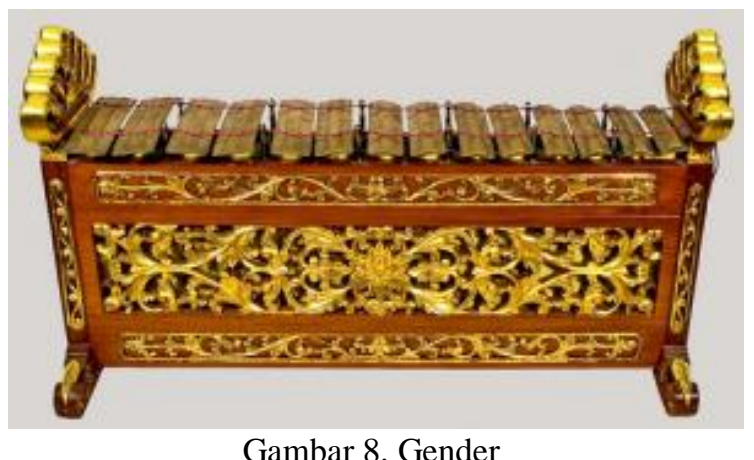

Instrumen terdiri dari bilah-bilah metal ditegangkan dengan tali di atas bumbungbumbung resonator. Gender ini dimainkan dengan tabuh berbentuk bulat (dilingkari lapisan kain) dengan tangkai pendek. Sesuai dengan fungsi lagu, wilayah nada, dan ukurannya, ada 
dua macam gender: (1) Gender barung dan (2) Gender panerus.

\section{Gambang}

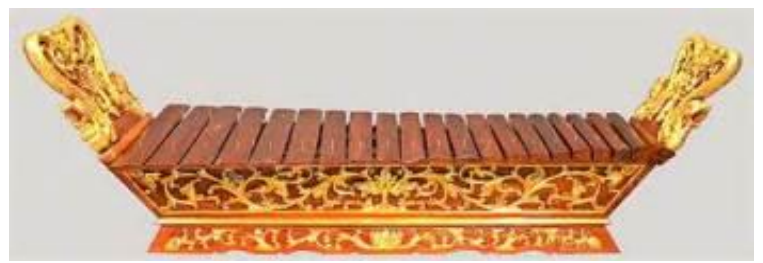

Gambar 9. Gambang

Instrumen dibuat dari bilah - bilah kayu dibingkai pada gerobogan yang juga berfungsi sebagai resonator. Berbilah tujuh-belas sampai dua-puluh bilah, wilayah gambang mencakup dua oktaf atau lebih. Gambang dimainkan dengan tabuh berbentuk bundar dengan tangkai panjang biasanya dari tanduk/sungu. Kebanyakan gambang memainkan gembyangan (oktaf) dalam gaya pola pola lagu dengan ketukan ajeg. Gambang juga dapat memainkan beberapa macam ornamentasi lagu dan ritme, seperti permainan dua nada dipisahkan oleh dua bilah, atau permainan dua nada dipisahkan oleh enam bilah, dan pola lagu dengan ritme - ritme sinkopasi.

\section{Rebab}

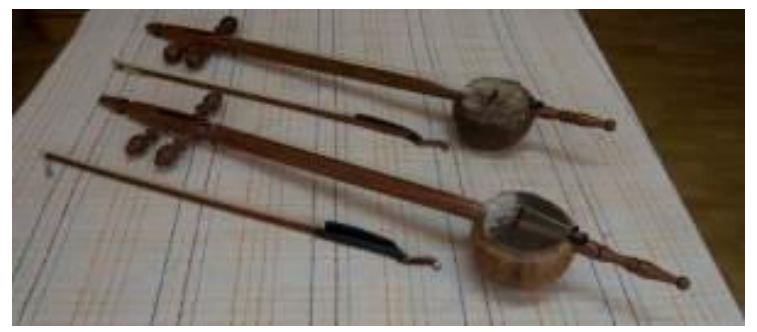

Gambar 10. Rebab

Instrumen kawat-gesek dengan dua kawat ditegangkan pada selajur kayu dengan badan berbentuk hati ditutup dengan membran (kulit tipis) dari babad sapi. Sebagai salah satu dari instrumen pemuka, rebab diakui sebagai pemimpin lagu dalam ansambel, terutama dalam gaya tabuhan lirih. Pada kebanyakan gendhinggendhing, rebab memainkan lagu pembuka gendhing, menentukan gendhing, laras, dan pathet yang akan dimainkan. Wilayah nada rebab mencakup luas wilayah gendhing apa saja. Maka alur lagu rebab memberi petunjuk yang jelas jalan alur lagu gendhing. Pada kebanyakan gendhing, rebab juga memberi tuntunan musikal kepada ansambel untuk beralih dari seksi yang satu ke yang lain.

Siter. Siter adalah sejenis kecapi dengan jajaran dawai, memakai tabung resonasi yang bertumpu pada kaki penunjang. Alat musik ini terdapat di Pulau Jawa.

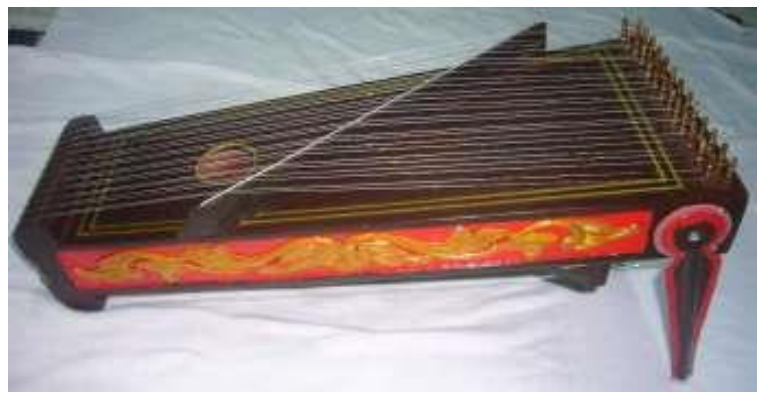

Gambar 11. Siter

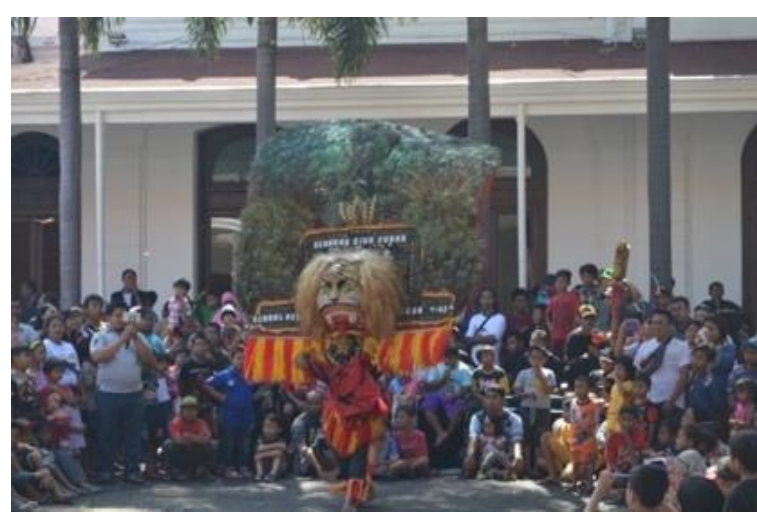

Gambar 12. Pertunjukan Reog Ponorogo

\section{Struktur Seni Pertunjukan}

Struktur seni pertunjukan tradisional yang dimaksud dalam penelitian ini adalah struktur atau susunan yang dibangun oleh seni pertunjukan Reog Ponorogo yang dipentaskan di Balai Pemuda Surabaya. Menurut Djelantik (1999:37), struktur atau susunan karya seni terdiri dari aspek-aspek yang menyangkut keseluruhan dari karya seni itu yang meliputi peranan masing-masing dalam keseluruhan karya tersebut. Lebih lanjut dijelaskan bahwa struktur mengandung arti bahwa di dalam karya seni terdapat suatu pengorganisasian, penataan, yang ada hubungan tertentu antara bagian-bagian yang tersusun itu. Sementara itu Peursen (dalam Djazuli, 1994:45) menjelaskan bahwa struktur adalah keadaan dan hubungan bagian dari suatu organisme yang berbentuk dalam wujud suatu tujuan keseluruhan dalam sebuah karya seni. Dalam struktur karya seni, terdapat elemen atau bagian yang terkait dan teroganisir guna terwujudnya suatu kesatuan bentuk karya seni. Sejalan dengan itu, Poloma (1992:25) menjelaskan bahwa struktur karya seni merupakan elemen yang saling terkait dan tidak dapat dilepaskan dengan elemen yang lain dan setiap bagian memberikan daya dukung bagi 


\section{Dhani Kristiandri \\ Mistisisme Musik Iringan Kesenian Reog Ponorogo}

terbentuknya satu kesatuan wujud karya itu.

Struktur adalah tata hubungan antara bagian atau unsur dalam membentuk satu keseluruhan, jadi berbicara tentang bentuk berarti berbicara tentang bagian-bagian. Dengan demikian, berbicara masalah bentuk penyajian juga berbicara masalah bagian-bagian dari bentuk pertunjukan (Royce dalam Indriyanto 1998/1999:15). Hal ini juga dikemukakan oleh Sedyawati (1981:110), yaitu dengan melihat bagaimana kehidupan seni yaitu dalam hal penyajiannya, yang juga dikaitkan dengan bentuk pengungkapan seniman dalam karyanya sehingga dapat ditangkap atau dirasakan penikmat dari bentuk fisik karya tersebut.

Konsep tersebut digunakan untuk menjelaskan struktur pertunjukan Reog Ponorogo ditinjau dari elemen dan struktur pertunjukan secara utuh pertunjukan yang tampil rutin di Balai Pemuda dalam bentuk kemasan pertunjukan.

Sebagai upaya untuk menghidupkan dan memperkenalkan keberadaan seni pertunjukan tradisional di masyarakat, Dinas Pendidikan Propinsi Jawa Timur dan Dinas Pariwisata kota Surabaya mengkemas seni pertunjukan tradisional dalam kemasan yang ditampilkan secara rutin. Pengkemasan pertunjukan ditampilkan secara periodik di berbagai tempat diantaranya pentas rutin di Taman Budaya Surabaya yang mengagendakan pentas tiap bulan dengan berbagai seni pertunjukan daerah yang ada di Jawa Timur. Pentas rutin setiap dua minggu sekali pertunjukan seni tradisional di Taman Hiburan Rakyat Surabaya dengan materi pertunjukan kesenian Ludruk, Wayang Orang dan Ketoprak. Balai Pemuda pada setiap hari minggu dengan seni pertunjukan Jaranan dan Reog Ponorogo.

Struktur karya seni merupakan elemenelemen yang saling terkait (hubungan) dan tidak dapat dilepaskan dengan elemen yang lain dan masing-masing. Dalam struktur pertunjukan Reog Ponorogo yang dipentaskan di Balai Pemuda Surabaya dapat dideskripsikan sebagai berikut:

\section{Persiapan.}

Pertunjukan Reog Ponorogo dimulai pukul 08.00 diawali dengan beberapa pengrawit yang mulai sibuk menata alat atau gamelan yang akan digunakan. Alat yang digunakan antara lain: satu buah Kendhang Bem, satu buah Kendhang Ketipung, dan satu buah Kendhang Ciblon. Tiga buah kenong dengan bentuk yang masing masing yang berbeda berlaras slendro, hal ini bertujuan untuk menciptakan bunyi yang khas dan menjadi ciri khas setiap pertunjukan reog ponorogo. Satu buah seronen atau selompret yang dibunyikan dengan cara di tiup, dengan mendendangkan lagu lagu khas reog ponorogo atau lagu jaman dahulu sebagai contoh misalnya lagu "Yen Ing Tawang Ana Lintang", "Walang Kekek", dan sebagainya. Dua buah Kempul dan 1 (satu) gong sebagai penanda berakhirnya bagian dari lagu. Satu buah bass drum dan 1 (satu) buah cymbal yang berfungsi sebagai penguat bunyi kendhang pada saat pukulan kuat pada kendang, sehingga pertunjukan tampak lebih meriah.

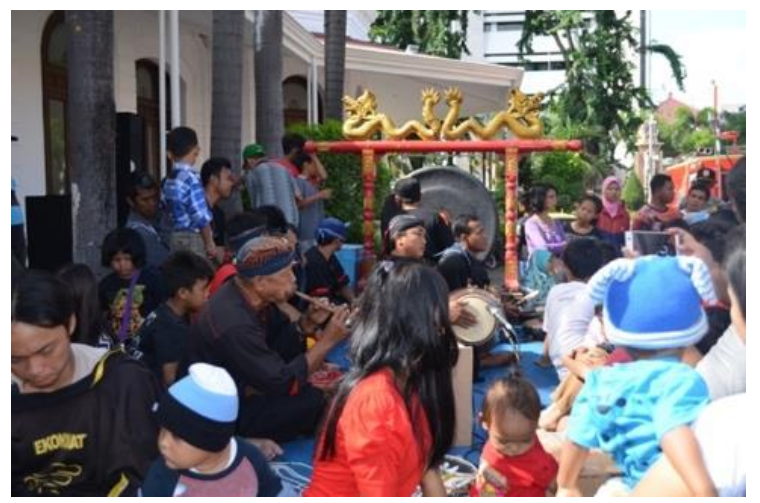

Gambar. 13 Beberapa Alat Musik atau Gamelan Reog Ponorogo

(Dok.Dhani Kristiandri: 2019)

Sambil menunggu pemain yang mempersiapkan diri, beberapa pemain mulai menyiapkan area pentas dengan cara mulai menata penonton dan pedagang untuk menjauh dari posisi alat atau gamelan yang sedang dimainkan. Para pemain mulai memainkan pecut sambil berteriak minggir -minggir. Kepada penonton yang berdiri dan dengan spontan penonton dan pedangang mulai berhamburan berlari kecil sambil tertawa kecil dan ada yang menangis karena takur dengan suara cambuk yang dimainkan oleh pemain. Kemudian pemain mulai menata dadag merag di samping area pentas yang nantinya akan dimainkan. Melihat Dadak Merak sudah ditata penonton langsung mendekat untuk melihat dari dekat seperti apa Dadak Merak tersebut kemudian penonton juga melakukan selfie dan ada yang memegang bulu bahkan ada beberapa anak ada yang mencoba mencabut bulu dari Dadak Merak tersebut. 


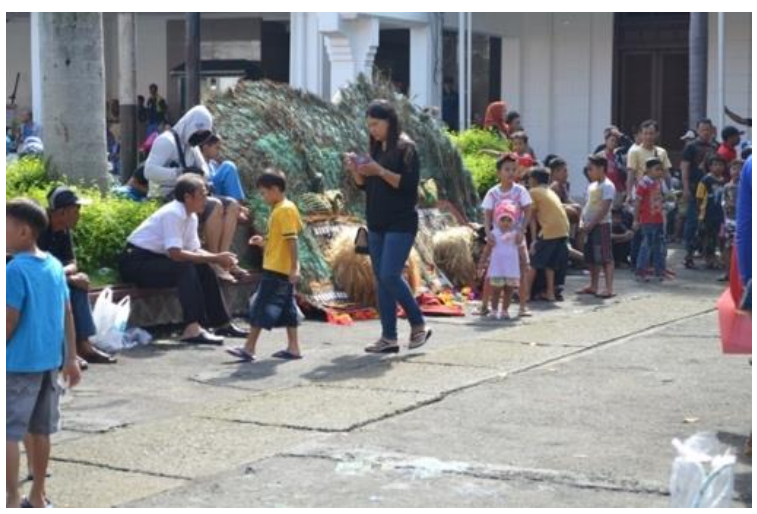

Gambar 14. Penonton mulai memadati area pertunjukan.

(Dok.Dhani Kristiandri: 2019)

Musik semakin lama semakin keras dan tempo yang semakin cepat menandakan bahwa pertunjukan akan segera dimulai. Penonton mulai membentuk lingkaran mengelilingi area pentas. Oleh karena jumlah penonton yang banyak serta anak kecil yang melihat juga antusias, maka penonton yang di depan dipersilakan untuk duduk di sekitar area pentas dengan beralaskan seadanya.

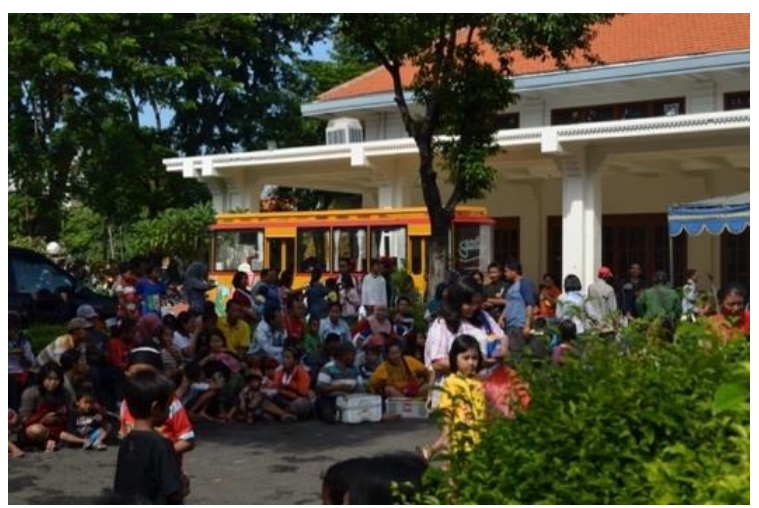

Gambar 15. Para penonton mulai duduk melingkar. (Dok.Dhani Kristiandri: 2019)

\section{Pertunjukan}

Pertunjukan diawali dengan dengan penampilan Dadak Merak, dengan jumlah penari dua orang. Penari mulai memutar-mutar tubuhnya sambil meliukkan topeng Dadak Merak yang digunakan beberapa kali dengan mengikuti irama gamelan yang dimainkan, sambil diiringi sorak sorai dan tepuk tangan penonton. Busana yang digunakan penari berupa kaos merah, celana hitam dengan hiasan rumbai-rumbai merah dan hitam, dilengkapi selendang terikat di pinggang, dan pemain tidak menggunakan alas kaki.

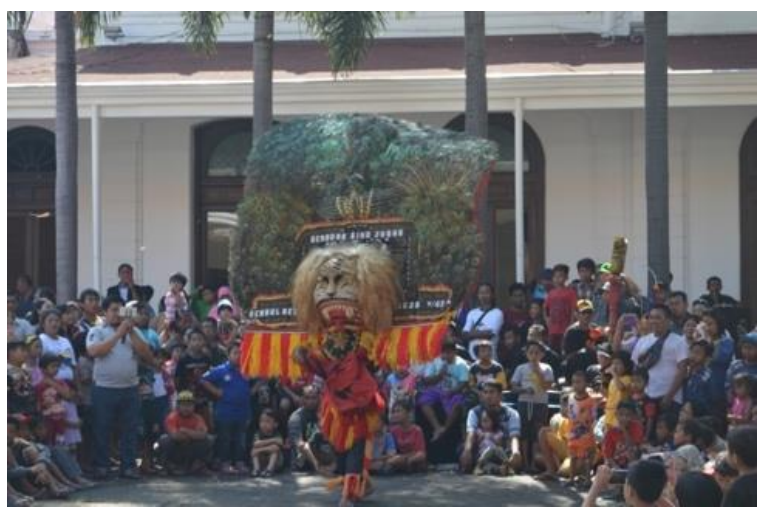

Gambar 16. Pertunjukan diawali dengan penampilan Dadak Merak

(Dok.Dhani Kristiandri: 2019)

Setelah 15 menit berjalan, muncul penari kedua juga menggunakan Dadak Merak, dengan pakaian sama seperti dengan penari pertama, namun berbeda kaosnya. Kaos yang digunakan penari kedua berwarna hitam. Penari kedua mulai unjuk kebolehan dengan meliukkan Dadak Merak secara cepat sebanyak 3 kali kemudian memutar tubuhnya ke belakang. Tangan penari berada di sisi kanan dan kiri Dadak Merak, bertujuan untuk menyangga sekaligus menahan Dadak Merak saat meliuk-liuk supaya tubuh Dadak Merak tidak jatuh.

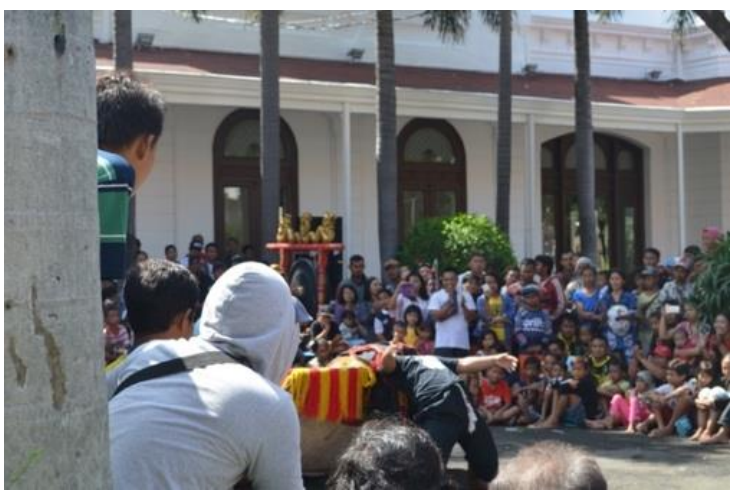

Gambar 17. Aksi pemeran Dadak Merak dengan berbagai keahliannya.

(Dok.Dhani Kristiandri: 2019) 


\section{Dhani Kristiandri \\ Mistisisme Musik Iringan Kesenian Reog Ponorogo}

Alunan musik semakin lama semakin cepat. Kedua Dadak Merak mulai saling berhadapan. Mulai berjalan berputar sambil mendekat ke arah penonton, tepuk tangan dan sorai penonton semakin riuh terdengar.

Kemudian dengan cepat keduanya saling meliukkan tubuhnya ke depan dan ke belakang, berkali kali mengikuti irama musik yang dimainkan.

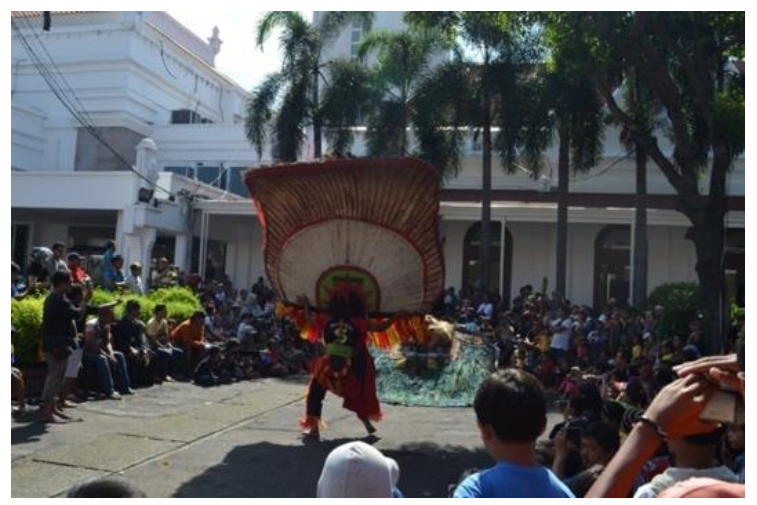

Gambar 18. Aksi pemeran Dadak Merak semakin memanas dan meliuk-liuk.

(Dok.Dhani Kristiandri: 2019)

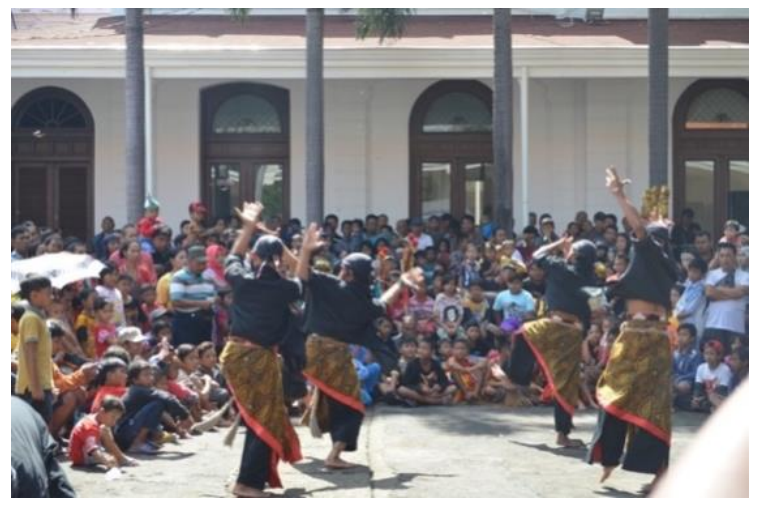

Gambar 19. Aksi pemeran Dadak Merak semakin menurun dan selesai.

(Dok.Dhani Kristiandri: 2019)

Setelah kurang lebih 30 menit, maka pertunjukkan Dadak Merak berakhir. Kemudian dilanjutkan dengan tarian yang kedua yaitu tarian Warok. Tarian Warok disini ditarikan oleh pemuda-pemuda setingkat SMP dan SMA berjumlah 4 orang. Pakaian yang digunakan baju hitam lengan panjang dan ditekuk sebatas lengan, celana hitam, memakai jarik dengan sabuk di pinggang serta tali putih besar. Untuk kepala memakai iket berwarna hitam, dan penari tidak memakai alas kaki. Untuk rias karena diumpakan sebagai Warok yang sudah agak tua, maka rias wajahnya cenderung berwarna merah dengan hiasan janggut yang lebat (brewok).

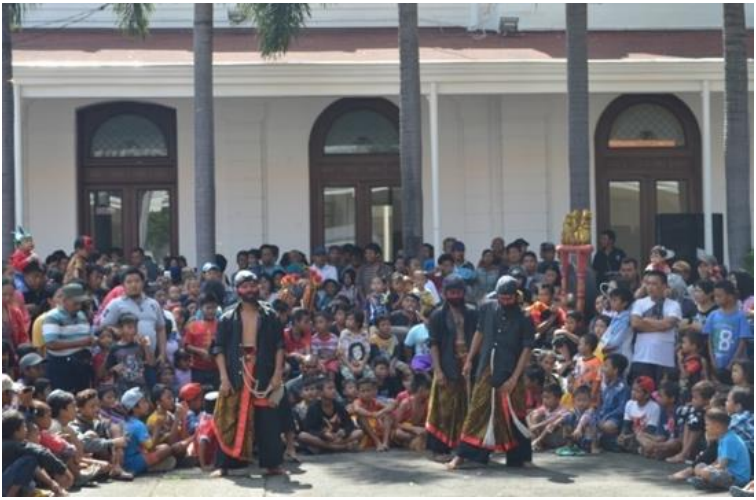

Gambar 20. Rias dan Busana pemeran Warok. (Dok.Dhani Kristiandri: 2019)

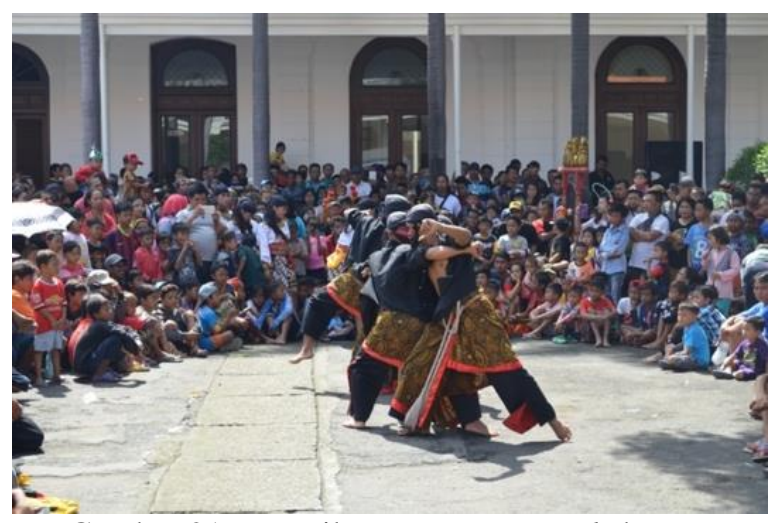

Gambar 21. Tampilan pemeran Warok dengan aksinya tarungan.

(Dok.Dhani Kristiandri: 2019)

Warok itu kuat, maka penggambaran gerakan tarian pada tarian Warok ini penuh dengan gerakan yang menonjolkan bentuk tubuh yang kuat, posisi tangan yang selalu dipinggang dan bahu yang diangkat seringkali terlihat pada tarian ini. Selain itu gerakan gerakan pencak silat mewarnai tarian ini, mulai dari posisi kuda-kuda, membungkuk dan menendang keatas serta kebawah tampak pada tarian ini. Dan tarin ini diakhiri dengan gerakan seperti bertarung yaitu dengan berhadapan, berangkulan, dan saling menendang.

Setelah kurang lebih 20 menit tarian Warok berakhir dan jeda sebentar, saat ini lah para pedagang mulai menjajakan dagannganya ke tengah area pementasan sambil mendekati penonton. Selain makanan dan minuman yang ditawarkan oleh pedagang, adalah pernik - pernik Reog Ponorogo, (mulai dari iket kepala, cambuk atau pecut, jaran kecil yang terbuat dari karton, selompret kecil, topeng, baju reog, celana reog dan lain sebagainya). 
Setelah sepuluh menit berlalu, maka acara mulai dilanjutkan dengan penampilan ketiga, yaitu tari jaranan atau Jathilan yang dimainkan oleh 4 orang penari putri yang cantik-cantik setingkat usia SMP dan SMA. Busana yang digunakan yaitu baju putih lengan panjang, celana pendek berwarna hitam dengan hiasan kuning emas dengan motif merak, memakai jarik dengan stagen warna merah melingkar di pinggang serta tidak lupa sabuk hitam dengan hiasan kuning emas sebagai pengikat selendang warna merah dan kuning di pinggang. Iket kepala berwarna hitam kemudian menggunakan asesoris kalung kace, selempang hitam, dan cambuk atau pecut terselip di belakang badan serta jaran kecil yang terbuat dari gedheg atau seseg atau bambu yang sudah diserut tipis dan dibentuk seperti kuda .

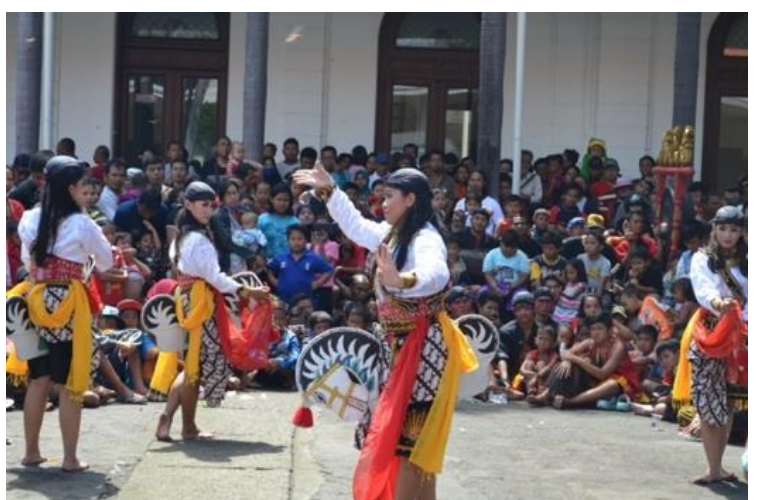

Gambar 22. Rias dan Busana pemeran Jaranan/Jathilan.

(Dok.Dhani Kristiandri: 2019)

Gerakan Tari Jaranan ini menggambarkan seorang yang sangat lihai mengendarai kuda. Gerakan meloncat loncat, berputar putar, badan membungkuk dan posisi duduk serta berdiri mengangkat kaki keatas secara bergantian sering terlihat pada tarian ini. Selain itu juga menjadi ciri khas penampilan reog disini, penari juga melakukan gerakan pencak silat mulai dari posisi kuda kuda, gerakan tendangan keatas dan kebawah sambil menaiki kuda dan memainkan pecut. Setelah kurang lebih 20 menit tarian Jaranan atau Jathilan ini diakhiri dengan posisi membentuk lingkaran dan berputar sambil memberi salam kepada penonton satu persatu dengan cara membungkuk kepada penonton.

Saat jeda berlangsung seorang pemain yang sekaligus menjadi pembawa acara memberi tahukan kepada penonton untuk minggir ke tepi karena area pementasan kurang luas, ternyata pada saat pertunjukkan berlangsung tadi banyak penonton yang maju mendekat ke penari, yang ingin melihat wajah penari dari dekat atau melakukan foto kepada penari sehingga area pentas menjadi sempit. Pecut pun akhirnya dimainkan sehingga penonton berhamburan ke tepi dan area pentas mulai terlihat lebar lagi.

Penampilan terakhir dari Reog Ponorogo dan sebagai penampilan puncak adalah tari topeng atau biasa disebut dengan tari penthul atau Bujangganong, dengan pemain berjumlah 7 orang berusia setingkat SD dan SMP. Busana yang dikenakan adalah baju merah celana hitam dengan memakai rumbai-rumbai warna merah dan kuning dengan gambar kepala harimau di tengahnya.

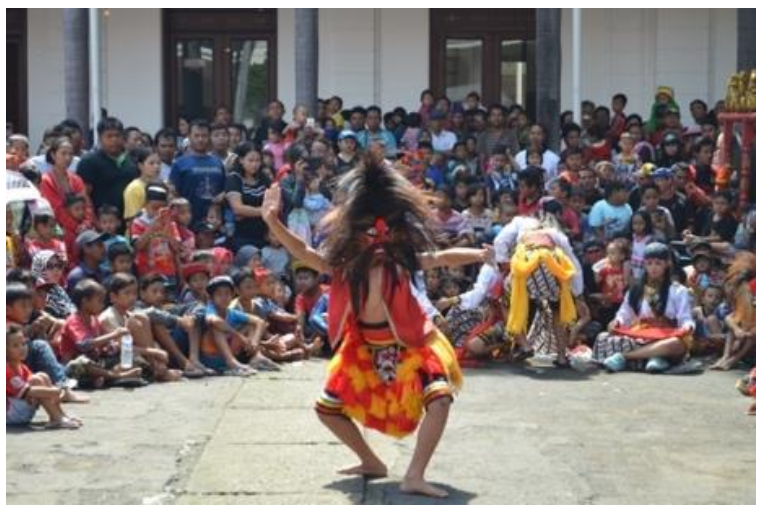

Gambar 23. Rias dan Busana Pemeran Bujangganong.

(Dok.Dhani Kristiandri: 2019)

Satu persatu penari mulai menunjukkan kepiawaiannya dalam menari penthul atau Bujangganong, gerakan mendhak, meloncatloncat, gerakan kepala menoleh kekanan dan kekiri kemudian kebawah dan keatas secara tegas dan cepat seakan-akan bahwa topeng yang dikenakan itu hidup. Gerakan berputar berputar mengelilingi penonton, gerakan melompat salto depan ataupaun salto belakang, berguling guling menjadi ciri khas tarian penthul tersebut.

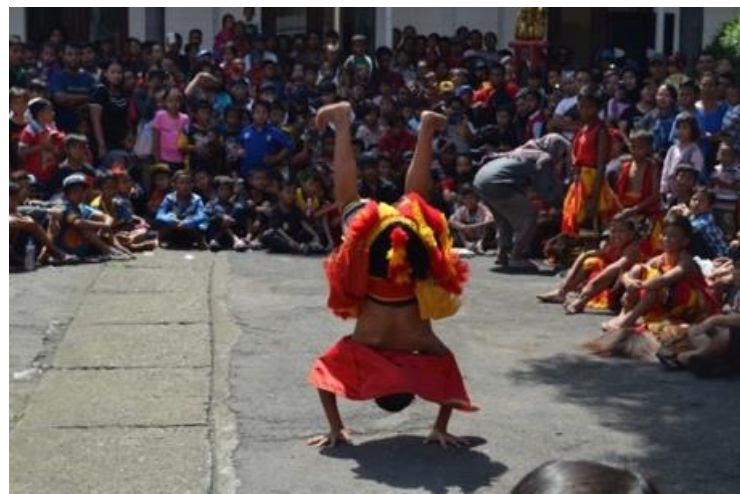

Gambar 24. Tampilan pemeran Bujangganong dengan aksinya yang acrobat. (Dok.Dhani Kristiandri: 2019) 


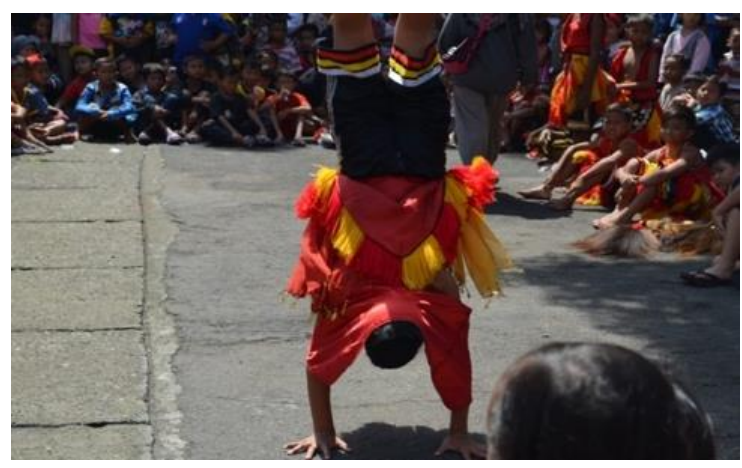

Gambar 25. Tampilan pemeran Bujangganong dengan aksi akrobatnya.

(Dok.Dhani Kristiandri: 2019)

Selain itu gerakan-gerakan lucu yang mengundang gelak-tawa juga disajikan disana, semisal gerakan garuk-garuk kepala, goyangan yang diarahkan ke penonton sering kali disajikan di sini. Di sela-sela tarian penthul atau Bujangganong, disajikan dagelan atau lawakan yang disajikan oleh pemain. Dimana penonton mulai melempar uang receh atau uang ribuan ke area pentas dan penari penthul atau Bujangganong berhamburan untuk mengambil uang tersebut. Teknik pengambilan ada berbagi macam cara dan hal ini menjadi tontonan yang menarik bagi penonton. Ada yang berlari kemudian menduduki uang tersebut supaya penari yang lain tidak tahu, kemudian baru diambil. Ada yang mengambil dari jarak jauh melakukan salto terlebih dahulu sampai mendekati ke arah uang tersebut. Ada yang seenaknya mengumpulkan dari penari yang lain dan kemudian masuk ke saku celana pemain tersebut. Ada yang gengsi kalau hanya uang 500 atau 100 rupiah tidak diambil dengan mengambil uang tersebut dan membuka topeng kalau nominal 1000 atau 500 dikembalikan ke pononton.

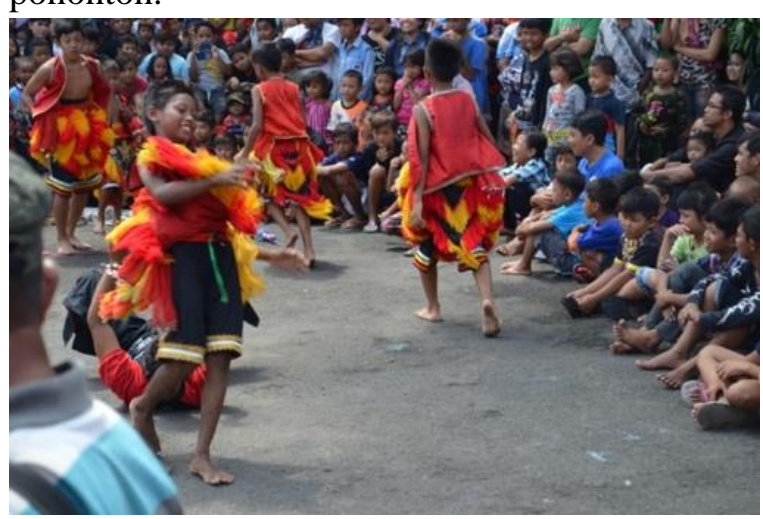

Gambar 26. Aksi para pemeran Bujangganong dalam aksinya saat mengambil saweran.

(Dok.Dhani Kristiandri: 2019)
Setelah kurang lebih 30 menit, pertunjukan diakhiri dengan melakukan salto satu persatu dengan dibantu pemain dewasa.

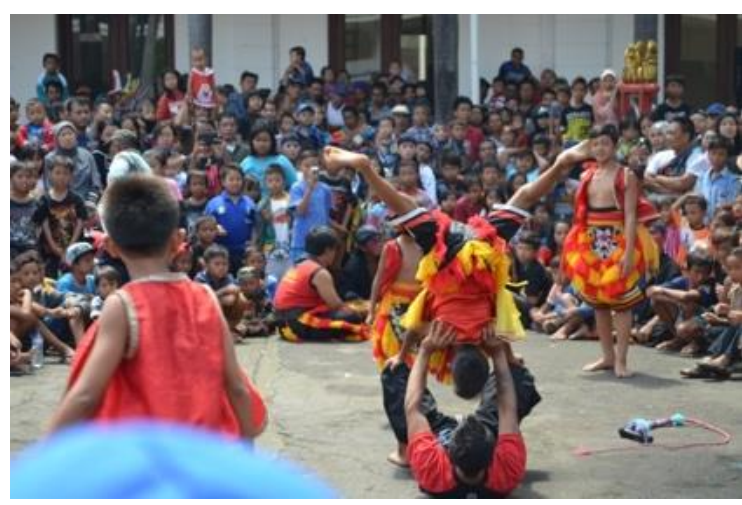

Gambar 27. Aksi akhir para pemeran Bujangganong. (Dok.Dhani Kristiandri: 2019)

\section{Fungsi Seni Pertunjukan.}

Seni pertunjukan tradisional dapat dikaji melalui fungsi seni bagi individu dan fungsi seni bagi masyarakat yang dapat disebut juga dengan fungsi sosial. Dalam kehidupan sehari-hari, fungsi seni berkaitan erat dengan fungsi estetis bagi seseorang sehingga perwujudannya pun dpat dituangkan dengan cara berkarya seni maupun mengapresiasi karya seni. Menurut Soekamto (1989:6), yang dimaksud fungsi seni adalah kegiatan kesenian yang mempunyai peranan penting dalam kehidupan masyarakat; sedangkan Sedyawati (1983:138) menjelaskan bagaimana suatu kesenian tradisional yang diciptakan oleh suatu masyarakat dapat mempunyai makna dan arti penting bagi masyarakatnya, dengan demikian kesenian tradisional yang hidup dalam kelompok masyarakat tertentu memiliki fungsi tertentu pula. Fungsi kesenian bagi masyarakat adalah sebagai sarana upacara, hiburan atau tontonan untuk dinikmati masyarakat umum.

Menurut Peursen (dalam Djazuli, 1994:36) dijelaskan bahwa fungsi selalu menunjukan terhadap sesuatu yang lain, apa yang namanya fungsional adalah sesuatu yang tidak dapat berdiri sendiri tetapi apabila dihubungkan dengan yang lain akan mempunyai arti dan maksud yang lain pula. Sebagai salah satu unsur kebudayaan, kesenian memiliki fungsi sebagai acuan pedoman bertindak bagi pendukungnya, dalam upaya memenuhi kebutuhan estetikanya.

Konsep tersebut digunakan untuk menjelaskan fungsi sosial pertunjukan Reog Ponorogo ditinjau dari fungsi seni bagi individu dan fungsi seni bagi masyarakat pada pertunjukan Reog Ponorogo di Balai Pemuda Surabaya. 
Seni pertunjukan tradisional dapat dikaji melalui fungsi seni bagi individu dan fungsi seni bagi masyarakat yang dapat disebut juga dengan fungsi sosial. Dalam kehidupan sehari-hari fungsi seni berkaitan erat dengan fungsi estetis bagi seseorang, sehingga perwujudannya pun dapat dituangkan dengan cara berkarya seni maupun mengapresiasi karya seni. Menurut Soekamto (1989:6), yang dimaksud fungsi seni adalah kegiatan kesenian yang mempunyai peranan penting dalam kehidupan masyarakat, sedangkan Sedyawati (1983:138) menjelaskan bagaimana suatu kesenian tradisional yang diciptakan oleh suatu masyarakat dapat mempunyai makna dan arti penting bagi masyarakatnya, dengan demikian kesenian tradisional yang hidup dalam kelompok masyarakat tertentu memiliki fungsi tertentu pula. Fungsi kesenian bagi masyarakat adalah sebagai sarana upacara, hiburan atau tontonan untuk dinikmati masyarakat umum.

Jika merujuk uraian pada bab sebelumnya bahwa, sebagai upaya untuk menghidupkan dan memperkenalkan keberadaan seni pertunjukan tradisional di masyarakat kota pada saat ini, Dinas Pendidikan Propinsi Jawa Timur dan Dinas Pariwisata kota Surabaya mengkemas seni pertunjukan tradisional dalam kemasan yang ditampilkan secara rutin dan periodik di Taman Budaya Surabaya ini menunjukkan, bahwa dalam eksistensi kesenian tradisional ini, khususnya kesenian Reog Ponorogo adalah tidak lepas dari peran agen atau actor dibelakangnya. Seperti yang dikatakan oleh Burns bahwa, agen manusia meliputi individu maupun kelompok terorganisir, organisasi dan bangsa (Jazuli, 2014:133) Agen atau actor dalam hal ini adalah dinas kota Surabaya yang telah mengatur dan mengkemas kesenian Reog Ponorogo untuk selalu tampil secara rutin di Taman Budaya Surabaya. Walaupun tidak menutup kemungkinan kelompok seni ini bisa tampil di lain tempat. Upaya-upaya semacam ini adalah sebagai wujud upaya pelestarian, sehingga kesenian Reog Ponorogo dapat berfungsi dan eksis bagi masyarakat pendukungnya pada jaman yang semakin modern.

Pergaulan global saat ini, mengarahkan masyarakat untuk mempunyai sikap yang individual dan egoism serta many value atau berkiblat pada uang. Pengaruh media massa yang menyebarkan faham konsumerisme, pewarisan nilai-nilai instan, internalisasi nilai-nilai global menyebabkan hilangnya nilai-nilai tradisi. Hal ini yang menginspirasi pihak dinas kota Surabaya mulai tergerak untuk mengkemas sajian seni tradisional yang ada di Jawa Timur agar tidak hilang ditelan zaman.

Selain itu menurut Peursen (dalam Djazuli, 1994:36) dijelaskan bahwa fungsi selalu menunjukan terhadap sesuatu yang lain, apa yang namanya fungsional adalah sesuatu yang tidak dapat berdiri sendiri tetapi apabila dihubungkan dengan yang lain akan mempunyai arti dan maksud yang lain pula. Sebagai salah satu unsur kebudayaan, kesenian memiliki fungsi sebagai acuan pedoman bertindak bagi pendukungnya, dalam upaya memenuhi kebutuhan estetikanya. Kesenian tradisional Reog Ponorogo jika dilihat dari sudut pandang manajemen produksi, penonton dapat juga dijadikan sebagai indikator atau tolok ukur keberhasilan dan kesuksesan suatu pertunjukan, karena pada dasarnya suatu pertunjukan seni tradisi saat ini seperti Reog Ponorogo ini lebih dimaksudkan sebagai sesuatu yang dipertontonkan kepada khalayak untuk dinikmati bersama sebagai fungsi social. Fungsi sosial yang dimaksud dalam hal ini adalah, bahwa kesenian tradisional Reog Ponorogo dalam masyarakat kota Surabaya yang semakin modern adalah sebagai fungsi hiburan rakyat.

\section{PENUTUP}

Struktur pertunjukan seni tradisional Reog Ponorogo diawali dengan penampilan Dadak Merak, dengan jumlah penari dua orang. Pemeran memutar - mutar tubuhnya sambil meliukkan topeng Dadak Merak yang digunakan beberapa kali mengikuti irama gamelan. Busana yang digunakan penari berupa kaos merah, celana hitam dengan hiasan rumbai-rumbai merah dan hitam, kemudian selendang terikat di pinggang, dan pemain tanpa menggunakan alas kaki. Urutan berikutnya adalah penampilan tarian Warok. Tarian Warok disini ditarikan oleh pemuda-pemuda setingkat SMP dan SMA berjumlah 4 orang. Berikut tampilan ketiga adalah penampilan tari Jaranan atau Jathilan yang dimainkan oleh 4 orang penari putri yang cantik - cantik setingkat usia SMP dan SMA. Penampilan terakhir dari Reog Ponorogo dan sebagai penampilan puncak adalah tari topeng atau biasa disebut dengan tari penthul atau Bujangganong, dengan pemain berjumlah 7 orang berusia setingkat SD dan SMP. Busana yang dikenakan adalah baju merah celana hitam dengan memakai rumbai - rumbai warna merah dan kuning dengan gambar kepala harimau di tengahnya. Di sela-sela tarian penthul atau Bujangganong disajikan dagelan atau lawakan 
yang disajikan oleh pemain.

\section{DAFTAR PUSTAKA}

Arikunto, Suharsimi. 1998. Prosedur Penelitian Suatu Pendekatan Praktek. Jakarta: Rineka Cipta.

Djazuli, M. 1994. Telaah Teoritis Seni Tari. Semarang: IKIP Semarang Press.

Djelantik, A.A.M. 1999. Estetika Sebuah Pengantar. Bandung: Masyarakat Seni Pertunjukan.

Haviland, 1975. Culture Antropology, New York: Holt, Rinehart and Wiston, Inc.

Indriyanto. 1998/1999. Lengger Banyumasan Kontinuitas dan Perubahannya, Tesis S2. Yogyakarta: UGM.

Moleong, J. Lexy. 2002. Metodologi Penelitian Kualitatif. Bandung: PT. Remaja Rosdakarya.

Murder, Niels.2001. Mistisisme Jawa, Ideologi Di Indonesia. Yogyakarta: LKiS.

Poloma, Margaret. 1992. Sosiologi Kontemporer, diterjemahkan oleh Tim Penterjemah Yosogama. Jakarta: Rajawali Pers.

Sedyawati, Edi. 1981. Pertumbuhan Seni Pertunjukan. Jakarta: Sinar Harapan. . 1983. Seni dalam Masyarakat Indonesia. Jakarta: Gramedia.

Soedarsono, R.M. 1999. Seni Pertunjukan Indonesia di Era Globalisasi. Jakarta: Direktorat Jendral Pendidikan Tinggi Depdikbud.

Soekanto, Soejono. 1989. Sosiologi Suatu Pengantar. Edisi Baru Jakarta: Rajawali Eka Press.

Yuwana, Setya, 1995. Reog Ponorogo Struktur Dramatik, Fungsi Sosial dan Makna Simbolik. Surakarta: MSPI

https://rininrhyti.wordpress.com/2015/08/17/alat -musik-yang-mengiringi-tari-reogponorogo/ 